\title{
Steciana
}

\section{POPULATION OF EPIPACTIS PALUSTRIS (L.) CRANTZ (ORCHIDACEAE) IN SOUTH-WESTERN PART OF POZNAŃ}

\author{
Magdalena KluZa-Wieloch, Irmina MaciejewsKa-RutKowsKa
}

\begin{abstract}
M. Kluza-Wieloch, Department of Botany, Poznań University of Life Sciences, Wojska Polskiego 71 C, 60-625 Poznań, Poland, e-mail: kluza@up.poznan.pl

I. Maciejewska-Rutkowska, Department of Forest Botany, Poznań University of Life Sciences, Wojska Polskiego 71 D, 60-625 Poznań, Poland, e-mail: irminamr@up.poznan.pl
\end{abstract}

(Received: October 13, 2015. Accepted: November 10, 2015)

\begin{abstract}
During the last 10 years (2005-2014) the population of Epipactis palustris within the former ecological use "Kopanina 1" was observed five times. In subsequent years, on the area of $4400 \mathrm{~m}^{2}$ at least 1000 to more than 4000 ramets were noted. The ramets in generative phase of development always predominated. It might indicate good condition of the population. The highest density per unit of area was observed in the first year of the study. The length of stems and number of leaves were the most constant features in orchid population. Then the width of the bract was characterized by the greatest values of the coefficient of variation. During the entire study period the number of ramets in population of E. palustris fluctuated, mainly resulting from the biology of the species, and only substantially from the impact of weather conditions. Negative impact of diverse human activities and excessive expansion of the other plant species, which resulted in the shading of the orchid sites, are the major threats to E. palustris existence in the described object.
\end{abstract}

KeY wORDS: Epipactis palustris, population, variability, urban aglomeration, Poznań

\section{INTRODUCTION}

The genus Epipactis Zinn. consists of about 10-30 species. There are two centers of its occurrence. The first covers the central and western Europe and the Mediterranean Basin, and second is located in the south-eastern part of Asia, as far as Vietnam and Thailand and southern China. Besides, the Epipactis species can be found in the northern and central Africa and North America (Mirek \& PięKoś-Mirkowa 2008). The presence of nine species of this genus has been documented in Poland so far (MireK et al. 2002). According to new Regulation of the Minister of the Environment (RozPorZAidzenIE... 2014) six of them, including E. palustris (L.) Crantz, are protected by law.

Marsh helleborine is an Eurosiberian species, but it also occurs in North Africa (BERNACKI 1999). This orchid grows on the sites up to $2000 \mathrm{~m}$ above sea level. It is reported throughout the Poland, but most of its sites are located in the southern part of the country, while in the central part this orchid is rela- tively rare. The highest site of E. palustris in Poland is known from the Gorce Mountains (Czoło Turbacza $1230 \mathrm{~m}$ above sea level; Szlachetкo \& SKakuj 1996). The latin species name "palustris" is derived from the world "palus" (swamp) and indicates the habitat of occurrence of this plant (Pię́Koś-Mirkowa \& MireK 2003). This orchid is often observed on the fens of Caricetalia davallianae order (MATUSZKIEWICZ 2006). It grows on the moist sites, in the places of water trickling, and on the black and groundwater gleyed soils. It prefers soils rich in carbonates, with slightly acid to alkaline pH (Pį̨Koś-Mirkowa \& Mirek 2003). In Poland the number of E. palustris sites has systematically decreased together with the disapperance of optimal habitats for the species (KUJAWA-PAWLACZYK \& PAWLACZYK 2001, ZARZYCKI \& SZELĄG 2006, WolANIN \& OKLejewicz 2011). The marsh helleborine is classified among the group of species at risk of extinction - V category (Mirek et al. 2006).

In recent years, both in Poland and in the world, the studies on marsh helleborine have been mainly concerned on its flowering biology, including the 
nectary structure, nectar composition, microorganisms that affect nectar, phenomenon of self-pollination, pollinators and palaeobotanical pollen analysis (Brzosko et al. 2004, 2006, Jakubska-Busse \& Kadej 2008, 2011, TaŁaŁaJ \& Brzosko 2008, GatKa \& Kasper 2011, JACQUEMYN et al. 2013, 2014, KowALKOWSKA et al. 2015). In addition, genetic variation of some other representatives of the genus Epipactis was analyzed (Ehlers \& Pedersen 2000, Brzosko et al. 2004, 2006). However, no comprehensive survey of the appearance on the secondary habitats and territorial occupancy by marsh helleborine has been carried out.

The aim of the study was to determine current population status and range of morphological variability of orchid ramets, on the site within the urban agglomeration, exposed to significance anthropopressure in different weather conditions, during the years of observations.

\section{STUDY AREA}

The study area is situated in the south-western part of the Poznań city. In 1994 two ecological uses "Kopanina I" and "Kopanina II" were set up here, with a total area of 126 hectares. The establishment of legal protection of this object was to protect the habitats of endangered species of birds, the unique, in the region, habitats of wet meadows and peatbogs, as well as endangered species of birds and flora of boggy sites (KLUZA \& MACIEJEWSKA 1999). In 2003, following amendment to the Law on the protection of nature, "Kopanina I" and "Kopanina II" lost the status of ecological uses. A gradual degradation connected with anthropopressure (as littering, running over land vehicles, stamped out of the area) and an expansion of vegetation composed of alien species,

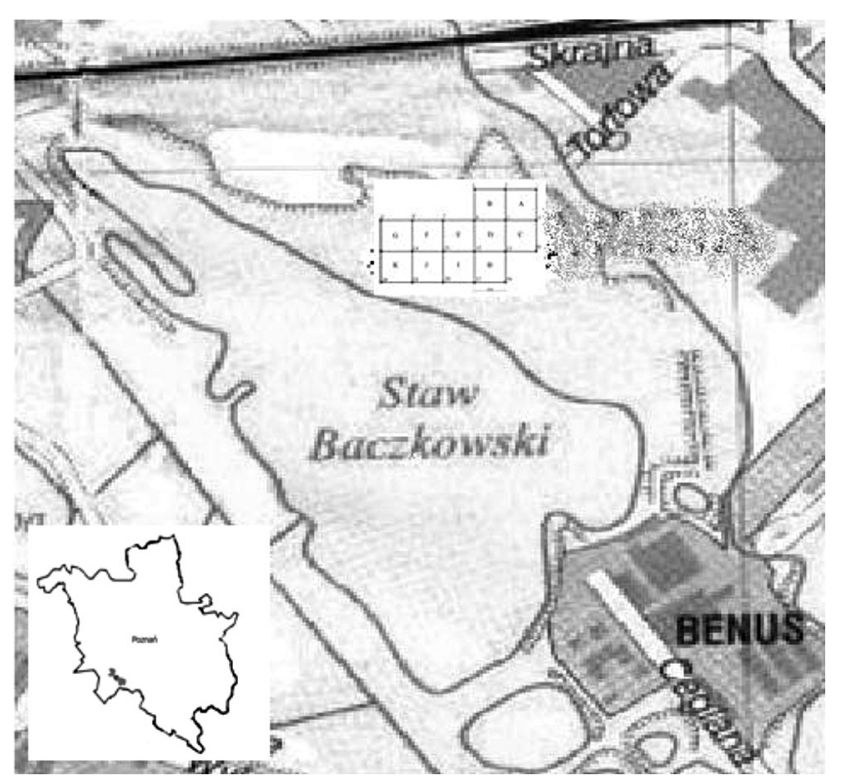

Fig. 1. Location of the study area in the south-western part of Poznań mainly Solidago canadensis, as well as excessive expansion of shrubs, also contributed to the cessation of protection of this area (FLESCH 2013).

The analyzed object is a part of former ecological use "Kopanina I". E. palustris population growths on the southeastern bank of the Baczkowski Pond. The pond was excavated as a result of exploitation of ceramic resources (varve loam and boulder clay) in the valley of the Junikowski stream - a small watercourse, which is a tributary of the Warta river). The exploitation of raw materials was carried out until the seventies of the last century. Now the vegetation of "Kopanina" consists of a mosaic of variously formed communities, as rushes, meadows, carpet plants and willow thickets. Baczkowski Pond, as one of the largest reservoir of this area, has been used for years by local inhabitants as a recreation ground ("wild" swimming pools, beaches, places for fishing). So, currently the vegetation is exposed here to strong anthropopressure, which takes different forms (KLUZA-WieLOCH \& MACIEJEWSKA-RUTKOWSKA 2009).

\section{MATERIAL AND METHODS}

Current study on the E. palustris population was carried out in the field five times: in 2005, 2009 and in the years 2012-2014. The fieldwork included a relatively large area of $4400 \mathrm{~m}^{2}$, along the bank of the pond (Fig. 1). For the study, the area was divided into 11 squares of the side $20 \mathrm{~m}$ long (Fig. 2) The vertices of these squares were determined using GPS. The whole area of research was located between $16^{\circ} 51^{\prime} 27.190^{\prime \prime}$ and $16^{\circ} 51^{\prime} 32.270^{\prime \prime}$ east longitude, and $52^{\circ} 22^{\prime} 37.000^{\prime \prime}$ and $52^{\circ} 22^{\prime} 38.950^{\prime \prime}$ north latitude. The exact location of the vertices of each square is shown in the development MACIEJEWSKA-RUTKOWSKA et al. (2008). The number of ramets on the entire area, and in the individual squares were determined in the years of observations. The average density per $1 \mathrm{~m}^{2}$ and percentage participation of marsh helleborine in particular squares were also calculated. Besides, the

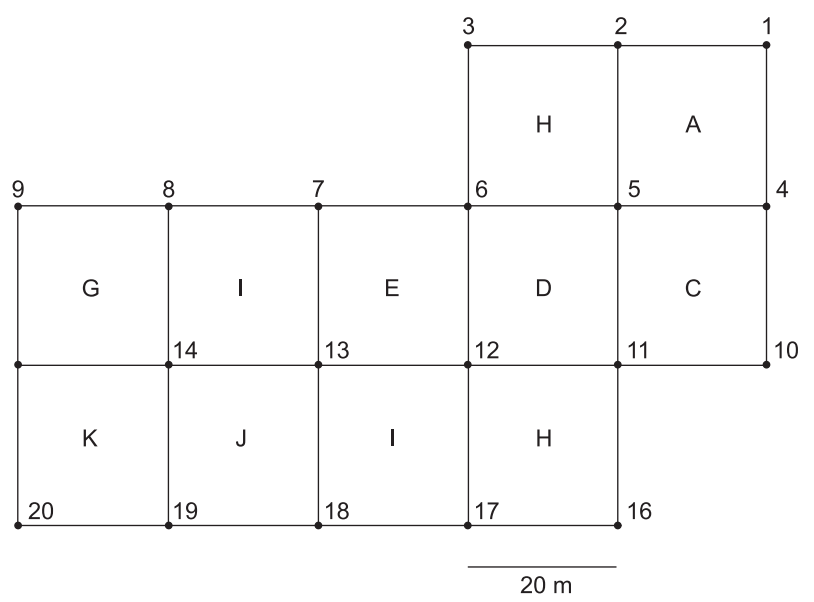

Fig. 2. Diagram of the research area, divided into plots 
participation of the ramets in vegetative and generative phases was described.

In the five-year observations (2005, 2009 and 2012 -2014), the length of stems and inflorescences were measured and flowers per inflorescence were counted. Additionally, the number of leaves, length and width of the largest leaf and the length and width of bract were determined. The data obtained allowed to carry out basic statistical analyses (Kala 2009). For at least 30 flowering ramets in population $(n=30$ -250 depending on the year of observation) arithmetic mean, median, variance, standard deviation and coefficient of variation were calculated: and minimum and maximum values of the features were determined.

The composition and structure of vegetation with E. palustris population in each of 11 areas of the plots was described in 2005, using BraUn-BlanQUET's method (MACIEJEWSKA-RUTKOWSKA et al. 2008). Nomenclature of vegetation was given according to Matuszkiewicz (2006).

Weather conditions in the years 2005-2014, during the growing season of the orchid, were also monitored. Meteorological data were obtained from the website (www.weatheronline.pl). For each month the average temperature $\left({ }^{\circ} \mathrm{C}\right)$ and precipitation $(\mathrm{mm})$ were calculated (Table 1).

\section{RESULTS}

Throughout the observation period population of Marsh helleborine was large, and in the first four seasons the number of ramets was similar - always

Table 1. Characteristics of temperature and precipitation during the growing season of Epipactis palustris (April - October) in the years of observations

\begin{tabular}{|c|c|c|c|c|c|c|c|c|c|c|c|c|c|c|c|c|c|c|c|c|}
\hline \multirow{3}{*}{ Month } & \multicolumn{5}{|c|}{ Mean temperature $\left({ }^{\circ} \mathrm{C}\right)$} & \multicolumn{5}{|c|}{ Minimum temperature $\left({ }^{\circ} \mathrm{C}\right)$} & \multicolumn{5}{|c|}{ Maximum temperature $\left({ }^{\circ} \mathrm{C}\right)$} & \multicolumn{5}{|c|}{ Precipitation amount (mm) } \\
\hline & \multicolumn{20}{|c|}{ Year } \\
\hline & 2005 & 2009 & 2012 & 2013 & 2014 & 2005 & 2009 & 2012 & 2013 & 2014 & 2005 & 2009 & 2012 & 2013 & 2014 & 2005 & 2009 & 2012 & 20132 & 2014 \\
\hline April & 9 & 11 & 9 & 8 & 11 & -5 & -1 & -5 & -6 & -2 & 20 & 26 & 30 & 26 & 22 & 16.4 & 16.4 & 16.4 & 15.8 & 64.5 \\
\hline May & 13 & 13 & 15 & 15 & 15 & 1 & 2 & 1 & 3 & 0 & 31 & 29 & 30 & 27 & 30 & 62.2 & 82.0 & 47.6 & 65.0 & 84.5 \\
\hline June & 16 & 16 & 16 & 17 & 17 & 2 & 3 & 6 & 8 & 7 & 33 & 29 & 30 & 34 & 31 & 16.8 & 96.8 & 94.4 & 127 & 38.0 \\
\hline July & 20 & 20 & 20 & 20 & 23 & 11 & 11 & 9 & 10 & 12 & 32 & 31 & 32 & 33 & 34 & 73.2 & 92.6 & 126 & 39.2 & 93.3 \\
\hline August & 17 & 19 & 19 & 19 & 18 & 8 & 8 & 6 & 9 & 6 & 28 & 31 & 35 & 33 & 33 & 48.6 & 13.8 & 33.4 & 33.4 & 29.1 \\
\hline September & 16 & 16 & 15 & 13 & 17 & 2 & 2 & 4 & 2 & 0 & 30 & 28 & 30 & 24 & 31 & 34.6 & 27.6 & 20.6 & 69.2 & 35.5 \\
\hline Mean/*Sum & 15.2 & 15.8 & 15.7 & 15.3 & 16.3 & 3.2 & 4.2 & 3.5 & 4.3 & 3.0 & 29.0 & 29.0 & 31.2 & 29.5 & 30.2 & $* 252$ & $* 329$ & $* 339$ & $* 350$ & $* 345$ \\
\hline
\end{tabular}

Table 2. Number of Epipactis palustris population within the former ecological use "Kopanina I" in Poznań, during the years of observations

\begin{tabular}{cccc}
\hline Year of observation & Number of generative ramets & Number of vegetative ramets & Total number of ramets \\
\hline 2005 & 3715 & 895 & 2035 \\
2009 & 2462 & 872 & 4497 \\
2012 & 3887 & 840 & 4759 \\
2013 & 3585 & 367 & 4425 \\
2014 & 762 & 129 \\
\hline
\end{tabular}

Table 3. Participation of Epipactis palustris ramets within the determined plots and their density

\begin{tabular}{|c|c|c|c|c|c|c|c|c|c|c|c|c|}
\hline Plot & Year & A & B & $\mathrm{C}$ & $\mathrm{D}$ & $\mathrm{E}$ & $\mathrm{F}$ & $\mathrm{G}$ & $\mathrm{H}$ & $\mathrm{I}$ & $\mathrm{J}$ & $\mathrm{K}$ \\
\hline \multirow{6}{*}{$\begin{array}{l}\text { Number of orchid } \\
\text { ramets }\end{array}$} & 2005 & 548 & 497 & 120 & 643 & 1972 & 281 & 221 & 114 & 204 & 4 & 6 \\
\hline & 2009 & 694 & 572 & 272 & 778 & 1574 & 184 & 71 & 153 & 197 & 0 & 2 \\
\hline & 2012 & 775 & 753 & 325 & 1006 & 1477 & 15 & 0.0 & 174 & 234 & 0 & 0 \\
\hline & 2013 & 341 & 609 & 61 & 978 & 1036 & 491 & 187 & 355 & 214 & 56 & 97 \\
\hline & 2014 & 193 & 157 & 89 & 277 & 203 & 115 & 47 & 42 & 6 & 0 & 0 \\
\hline & 2005 & 11.9 & 10.8 & 2.6 & 13.9 & 42.8 & 6.1 & 4.8 & 2.5 & 4.4 & 0.1 & 0.1 \\
\hline \multirow{4}{*}{$\begin{array}{l}\text { Percentage partici- } \\
\text { pation of ramets in } \\
\text { population }(\%)\end{array}$} & 2009 & 15.4 & 12.7 & 6.0 & 17.3 & 35.0 & 4.1 & 1.6 & 3.4 & 4.4 & 0.0 & 0.1 \\
\hline & 2012 & 16.3 & 15.8 & 6.8 & 21.1 & 31.0 & 0.3 & 0.0 & 3.7 & 4.9 & 0.0 & 0.0 \\
\hline & 2013 & 7.7 & 13.8 & 1.4 & 22.1 & 23.4 & 11.1 & 4.2 & 8.0 & 4.8 & 1.3 & 2.2 \\
\hline & 2014 & 17.1 & 13.9 & 7.9 & 24.5 & 18.0 & 10.2 & 4.2 & 3.7 & 0.5 & 0.0 & 0.0 \\
\hline \multirow{5}{*}{$\begin{array}{l}\text { Orchid density } \\
\text { per } 1 \mathrm{~m}^{2}\end{array}$} & 2005 & 1.37 & 1.24 & 0.30 & 1.61 & 4.93 & 0.70 & 0.55 & 0.28 & 0.51 & 0.01 & 0.01 \\
\hline & 2009 & 1.74 & 1.43 & 0.68 & 1.95 & 3.94 & 0.46 & 0.18 & 0.38 & 0.49 & 0.00 & 0.01 \\
\hline & 2012 & 1.94 & 1.88 & 0.81 & 2.56 & 3.69 & 0.04 & 0.00 & 0.44 & 0.59 & 0.00 & 0.00 \\
\hline & 2013 & 0.85 & 1.52 & 0.15 & 2.45 & 2.59 & 1.23 & 0.47 & 0.89 & 0.54 & 0.14 & 0.24 \\
\hline & 2014 & 0.48 & 0.39 & 0.22 & 0.69 & 0.51 & 0.29 & 0.12 & 0.11 & 0.02 & 0.00 & 0.00 \\
\hline
\end{tabular}


Magdalena Kluza-Wieloch, Irmina Maciejewska-Rutkowska

Table 4. Characteristics of selected morphological traits of Epipactis palustris in the years of research

\begin{tabular}{|c|c|c|c|c|c|c|c|}
\hline Year & Mean & Minimum & Maximum & Mediana & Variance & $\begin{array}{l}\text { Standard } \\
\text { deviation }\end{array}$ & $\begin{array}{l}\text { Variation coefi- } \\
\text { cient }(\%)\end{array}$ \\
\hline \multicolumn{8}{|c|}{ Height of stem $(\mathrm{cm})$} \\
\hline 2005 & 59.61 & 42.0 & 73.0 & 54.5 & 92.16 & 9.60 & 16.10 \\
\hline 2009 & 65.60 & 47.0 & 80.5 & 66.0 & 55.65 & 7.46 & 11.37 \\
\hline 2012 & 57.00 & 35.0 & 71.0 & 55.5 & 77.45 & 8.80 & 15.44 \\
\hline 2013 & 53.82 & 34.0 & 69.0 & 56.0 & 71.99 & 8.48 & 15.76 \\
\hline 2014 & 53.45 & 32.3 & 78.1 & 51.9 & 98.84 & 9.94 & 18.60 \\
\hline \multicolumn{8}{|c|}{ Length of inflorescence $(\mathrm{cm})$} \\
\hline 2005 & 17.85 & 7.0 & 30.0 & 14.0 & 32.49 & 5.70 & 31.96 \\
\hline 2009 & 15.27 & 9.0 & 21.0 & 13.0 & 10.95 & 3.31 & 21.65 \\
\hline 2012 & 23.57 & 17.0 & 31.0 & 19.0 & 18.21 & 4.27 & 18.11 \\
\hline 2013 & 19.50 & 11.0 & 29.0 & 20.0 & 23.11 & 4.81 & 24.67 \\
\hline 2014 & 6.71 & 2.2 & 15.7 & 5.6 & 11.60 & 3.41 & 50.76 \\
\hline \multicolumn{8}{|c|}{ Number of flowers per inflorescence } \\
\hline 2005 & 20.76 & 9 & 38 & 25.0 & 37.94 & 6.16 & 29.67 \\
\hline 2009 & 17.80 & 9 & 26 & 18.0 & 20.16 & 4.49 & 25.23 \\
\hline 2012 & 21.60 & 15 & 26 & 23.0 & 11.00 & 3.32 & 15.36 \\
\hline 2013 & 19.58 & 8 & 28 & 20.0 & 26.17 & 5.12 & 26.15 \\
\hline 2014 & 18.40 & 7 & 25 & 18.5 & 23.49 & 4.85 & 26.34 \\
\hline \multicolumn{8}{|c|}{ Number of leaves } \\
\hline 2005 & 6.30 & 5 & 8 & 6 & 0.68 & 0.83 & 13.28 \\
\hline 2009 & 6.55 & 5 & 8 & 7 & 0.60 & 0.78 & 11.95 \\
\hline 2012 & 7.67 & 5 & 9 & 7.5 & 1.44 & 1.20 & 15.65 \\
\hline 2013 & 6.34 & 5 & 9 & 6 & 0.88 & 0.94 & 14.83 \\
\hline 2014 & 6.97 & 4 & 9 & 7 & 1.48 & 1.22 & 17.41 \\
\hline \multicolumn{8}{|c|}{ Length of the largest leaf $(\mathrm{cm})$} \\
\hline 2005 & 8.73 & 5.5 & 12.0 & 11.0 & 3.68 & 1.92 & 22.03 \\
\hline 2009 & 12.63 & 7.0 & 18.0 & 13.0 & 7.34 & 2.71 & 21.48 \\
\hline 2012 & 9.99 & 7.5 & 15.0 & 10.0 & 3.12 & 1.77 & 17.72 \\
\hline 2013 & 10.86 & 7.0 & 15.0 & 11.0 & 4.68 & 2.16 & 19.89 \\
\hline 2014 & 12.90 & 7.8 & 18.2 & 12.5 & 9.04 & 3.01 & 23.31 \\
\hline \multicolumn{8}{|c|}{ Width of the largest leaf $(\mathrm{cm})$} \\
\hline 2005 & 3.32 & 2.5 & 4.5 & 2.50 & 0.47 & 0.69 & 20.76 \\
\hline 2009 & 2.79 & 2.0 & 4.5 & 3.00 & 0.40 & 0.64 & 23.02 \\
\hline 2012 & 3.95 & 3.0 & 6.0 & 4.00 & 0.68 & 0.83 & 21.01 \\
\hline 2013 & 1.87 & 1.2 & 3.8 & 1.80 & 0.36 & 0.60 & 32.09 \\
\hline 2014 & 3.50 & 1.9 & 5.8 & 3.25 & 0.95 & 0.97 & 27.75 \\
\hline \multicolumn{8}{|c|}{ Length of bract $(\mathrm{cm})$} \\
\hline 2005 & 2.92 & 1.5 & 6.0 & 3.0 & 1.29 & 1.14 & 39.13 \\
\hline 2009 & 3.30 & 1.5 & 6.0 & 3.0 & 1.56 & 1.25 & 37.87 \\
\hline 2012 & 4.82 & 3.0 & 7.0 & 5.0 & 1.76 & 1.33 & 27.59 \\
\hline 2013 & 3.17 & 1.6 & 4.6 & 3.2 & 0.42 & 0.65 & 20.50 \\
\hline 2014 & 3.15 & 1.4 & 6.7 & 2.9 & 1.46 & 1.21 & 38.35 \\
\hline \multicolumn{8}{|c|}{ Width of bract $(\mathrm{cm})$} \\
\hline 2005 & 0.61 & 0.2 & 1.1 & 0.4 & 0.10 & 0.32 & 52.46 \\
\hline 2009 & 0.46 & 0.2 & 3.0 & 0.4 & 0.27 & 0.22 & 47.83 \\
\hline 2012 & 1.07 & 0.8 & 3.0 & 1.0 & 0.87 & 0.67 & 62.62 \\
\hline 2013 & 0.70 & 0.3 & 1.1 & 0.7 & 0.03 & 0.18 & 25.71 \\
\hline 2014 & 0.54 & 0.2 & 1.2 & 0.5 & 0.06 & 0.25 & 45.78 \\
\hline
\end{tabular}


more than 4,000 orchids were noted (Table 2). Most of stems (4759) were observed in 2012, and the least (1129) in the last year of the study - 2014. The highest number of ramets in the vegetative stage of growth was recorded in 2009 (2035), and the least also in 2014 (367). Vegetative shoots in 2009 were up. In the remaining three years of research, the number of such ramet was also balanced, varied from 840 to 895 units. Most flowering orchids were noted in 2012 (3887), and the lowest in 2014 (762). However, the percentage stems in generative phase of development in population was the smallest in 2009 - only $54.8 \%$ (Table 2 ).

Usually, within all 11 research plots, the largest number of ramets was noted in the square $\mathrm{E}$, with minimum 203 (2014) and maximum 1972 (2005, Table 3). This plot was located in the central part of the entire research area (Fig. 2). Only in the last year of the study the most ramet were found in the square D (277). Similarly, the highest density of E. palustris was noted in the plot E $\left(4.93 / 1 \mathrm{~m}^{2}\right)$ in 2005 . In the three years of observation no ramets were found in some plots. That was plot J in 2009, G, J and $\mathrm{K}$ in 2012 and $\mathrm{J}$ and $\mathrm{K}$ in 2014. The lowest number of ramets was always observed in a square J. In two squares $\mathrm{K}$ and $\mathrm{J}$, which usually were characterized by single stems or were without any stem only in 2013 dozens of ramets were found (Table 3 ). These plots were located closest to the edge of the pond (Fig. 1), with the most humid, peat soil, rich in humus. At the same time these squares were subjected to the strongest human pressure (trampling and littering). Other plots were higher ground, in more dry area and were with the highly cohesive, initial soils in the lower parts of clay excavation.

The plots F, I, J and $\mathrm{K}$ were covered by the vegetation of the Caricetum acutiformis and Phragmitetum australis associations (Phragmitetea class), with predominant Carex acutiformis and Phragmites australis. Additionally, the significant participation of shrubs (about 35\%), mainly Salix purpurea and S. cinerea, was noticed in plot $\mathrm{F}$. The other seven plots were grown by the species of Molinio-Arrhenatheretea class, but small areas were also covered by species chraracteristic for Phragmitetum australis. There were also a small number of species of Scheuchzerio-Caricetea nigrae class scattered on the entire research area (MACIEJEWSKA-RUTKOWSKA et al. 2008).

The average length of stems in the years of the study ranged from 53.45 to $65.65 \mathrm{~cm}$ with minimum $32.3 \mathrm{~cm}$ and maximum $80.5 \mathrm{~cm}$ (Table 4). The longest stems were observed in 2009 and the shortest in 2014. In the same year the inflorescences were the shortest (just $6.71 \mathrm{~cm}$ ). Generally the length of inflorescences ranged from $2.2 \mathrm{~cm}$ to $31 \mathrm{~cm}$, and its average value was the largest in $2012(23.57 \mathrm{~cm})$. The average number of flowers per raceme was also the largest in 2012. During the entire study the num- ber of flowers ranged from 7 up to 38. On average the smallest number of flowers per inflorescence was observed in 2009 (18). On average the smallest number of leaves per stem was noted in 2005 (6) and the largest in 2012 (8). During the whole period of observations the number of leaves per ramet ranged from 4 to 9 . On average the longest (at least $12.6 \mathrm{~cm}$ ) leaves were observed in 2009 and 2014 and the widest $(3.95 \mathrm{~cm})$ in 2012 . While, on average the shortest $(8.73 \mathrm{~cm})$ leaves were noted in 2005 and the narrowest $(1.87 \mathrm{~cm})$ in 2013 . Generally the length of the leaves ranged from $5.5 \mathrm{~cm}$ to $18.2 \mathrm{~cm}$ and the width from $1.2 \mathrm{~cm}$ to $6.0 \mathrm{~cm}$. On average the largest bracts were measured in 2012 (length $=4.82 \mathrm{~cm}$ and width $=1.07 \mathrm{~cm}$ ). and the smallest, with shortest $(2.92 \mathrm{~cm})$ bract in 2005 and the narrowest $(0.46 \mathrm{~cm})$ in 2009.

In the years of observations the length of stems and number of leaves were the most constant features (Table 4). For both those characteristics the values of the coefficient of variation never exceeded $20 \%$. The smallest variation of the length of stem was in 2009 (11.37\%). The width of the bract was characterized by the greatest values of the coefficient of variation, with a maximum in 2012, averaging an incredible $62.62 \%$ (Table 4 ).

\section{DISCUSSION}

In the last year of the current study (2014) decline in the population size of E. palustris can be explained by the occurrence of a plant rest phenomenon characteristic of native orchid species. It consists in cyclical non-disclosure of aboveground parts. According to Brzosкo (1998) this phenomenon in the family Orchidaceae is extremely important for the species population dynamics. The authors also watched this phenomenon in relation to the population of Dactylorhiza incarnata, growing nearby, along the bank of the Baczkowski Pond (Kluza-Wieloch \& MaciejewSKA-RUTKOWSKA 2009). During over ten years of observations only twice single stems or no ramets of $D$. incarnata were observed. While in the subsequent years the size of population was near the average (KluZa-Wieloch \& MaciejeWSKa-RutKowsKa 2009).

A decline in the population size of E. palustris in the last year of the study could not be explained by worse weather conditions (as drought or frost in the early stages of plant development) as well as by rapidly progressive succession of shrubs, and high grasses, competing for light or intensification of human activity. This phenomenon also failed to explain regarding to $D$. incarnata (KLUZA-Wieloch \& MAciejewsKA-RUTKOWSKA 2009).

Since 1997 the authors had carried out field observations of some Orchidaceae species within the mentioned above former ecological uses "Kopanina I" and "Kopanina II" (Kluza \& Maciejewska 1998). 
It was proved a spring burning reed-sedge rushes to be the most harmful human activity, having a negative impact both on flora and fauna. Fortunately, this practice ended at the beginning of the new century here. Appearing before the stems of $D$. incarnata under fire were partially damaged, however it did not adversely affect the emerging much later ramets of E. palustris. On the contrary it made easy access to light for this orchid. Therefore, in the future, if the population of E. palustris began to disappear it would be advisable to start works consisting of mowing the site of this orchid. The other threat to the object were trampling paths, using sites near the pond for sunbathing and angling and littering the area.

During nearly 20 years of the research in the surroundings of the Baczkowski Pond no significant expansion of the shrubby species was noted. In plot F, with the largest dominance of shrubs within the entire investigated area, only the growth of shrubs of $\mathrm{Sa}$ lix genus already pre-existing had been observed, but without the emergence of young willow specimens. A bigger threat to this photophilous species was overgrowing of its habitats by Phragmites australis.

Detailed studies on E. palustris populations in sites of natural origin were carried out in the Wielkopolska National Park (ANTKOWiak \& PANKRos 2000), in the "Mielno" reserve near Konin (Golis \& BEDNORZ 2001) and in the Augustów Primeval Forest (Kolon et al. 1995). AntKowiak \& PANKros (2000) carried out research into E. palustris population located on a wet meadow near the Łódź village in the Wielkopolska National Park. The observed orchid specimens were significantly higher $(74.96 \mathrm{~cm})$ than in current study. They were also characterised by a higher number of leaves (8) and longer leaves $(14.68 \mathrm{~cm})$ and bracts $(6.1 \mathrm{~cm})$, On the other hand they had fewer flowers per raceme (16). Length of inflorescences $(16.2 \mathrm{~cm})$, width of leaves $(3.78 \mathrm{~cm})$ and bracts $(0.64 \mathrm{~cm})$ were similar to the current population. Total number of ramets in the Wielkopolska National Park population was smaller (3377) than in population in Kopanina in first four years of current study but population density per area unit was larger $-4.97 / \mathrm{m}^{2}$.

The results obtained by Golis \& BEDNORz (2001) in "Mielno" reserve near Konin showed that E. palustris specimens growing on a wet meadow, near bank of the lake had distinctly shorter stems $(40.22 \mathrm{~cm})$ and inflorescences $(8.03 \mathrm{~cm})$ with fewer flowers (8) and leaves (6) and also smaller size of leaves (9.38 $\mathrm{cm}$ and $2.67 \mathrm{~cm}$ ), than currently observed orchid from the Poznań. The size population from Mielno did not exceed 300 ramets and population density by area unit was $4.1 / \mathrm{m}^{2}$.

Predominance of not flowering specimens $(82.6 \%)$ was noted in the E. palustris population located by the Pomorze Lake in the Augustów Forest (Kolon et al. 1995). The average height of orchids $(57.87 \mathrm{~cm})$ there described was very similar to those from current study in Poznań, but they had much shorter inflorescences $(9,71 \mathrm{~cm})$ and fewer number of flowers (9) and leaves (7). The leaves were longer $(13.28 \mathrm{~cm})$, but narrower $(2.75 \mathrm{~cm})$ and the bracts were shorter $(2.58 \mathrm{~cm})$ and narrower $(0.61 \mathrm{~cm})$.

Mróz \& Rudecki (1995) and WyrzyKiewicz-RASZEWSKa (2001) researched into E. palustris populations from anthropogenically transformed habitats. A very large population of marsh heleborine on the railway embankment in Poznań, near Koziegłowy village was found in 1999 (WYrzyKiEWICZ-RAsZEWSKA et al. 2001). Due to the size of the population, estimated at even tens of thousands of ramets, it was divided into three investigated areas (WYrzYKIEWICZ-RaszewsKa 2001). Depending on the plot, average height of stems $(48.2-62.2 \mathrm{~cm})$ and size of bracts (length $-4.44-6.34 \mathrm{~cm}$ and width $-0.53-0.74 \mathrm{~cm}$ ), was smaller or larger than in populations from "Kopanina", but their inflorescences were always shorter $(9.08-11.86 \mathrm{~cm})$ and they also had got less flowers (11-16), and leaves (6-7). Instead, their leaves were longer $(10.88-15.00 \mathrm{~cm})$, but at the same time narrower $(2.20-2.81 \mathrm{~cm})$. Population density near Koziegłowy was extremely high and even more than 200 ramets per $1 \mathrm{~m}^{2}$ were observed, with the average density about $65 / \mathrm{m}^{2}$. Within "Kopanina" population density was much smaller.

According to Mróz \& RUdeCKI (1995) E. palustris stems growing in the quarry at the cement works "Odra" in Opole were much lower $(33.8-41.7 \mathrm{~cm})$ than in both populations from "Kopanina". They also had shorter racemes $(7.3-12.2 \mathrm{~cm})$, with fewer flowers (7-11). The number of leaves (7) was slightly smaller, and the leaf length was comparable (9.6-9.9 $\mathrm{cm})$. The leaves of orchids in the quarry were narrower $(2.4-2.6 \mathrm{~cm})$ than those from Poznań, and the bracts were smaller (length 3.4-4.0 and width 0.5-1.6 $\mathrm{cm})$. The entire population in the quarry consisted of 400 ramets, with the density 25-37 per $1 \mathrm{~m}^{2}$.

As in the currently studied population, the width of the bract was the most variable feature $(\mathrm{CV}=$ $37.5 \%)$, but in population from the Wielkopolska National Park its variability level was lower. Then in both populations the length of stem (11.8\%) and number of leaves (14.09\%) were the most constant features. Moreover, the orchids from the Wielkopolska National Park were characterised by a small variation of leaf size (length $15.19 \%$ and width $16.14 \%$; AntKowiak \& Pankros 2000). The values of coefficient of variations of almost all traits of this E. palustris population were larger than in population growing in "Kopanina". Only number of leaves was characterised by less value of this indicator $(11.46 \%)$ compared to currently studied orchid population. The length of inflorescence was the most variable trait in the "Mielno" reserve - with CV $=42.69 \%$ (GoLIs \& BEDNORZ 2001). The length of inflorescence (21.9\%) and number of flowers per raceme $(34.1 \%)$ in $E$. 
palustris population from the Augustów Forest were more variable than in population from "Kopanina", but the length of the longest leaf was more constant (16\%; Kolon et al. 1995). In turn, the values of coefficient of variation of stem length (14.63-15.45\%), number of leaves (14.54-16.42\%), length of leaves (20.25-22.77\%) and length of inflorescences (28.58$-31.08 \%)$ in population from northen Poznań near Koziegłowy (WYRZYKIEWICZ-RASZEWSKA 2001) were similar to those calculated for the currently analysed orchid population and they were within the resulting five-year variation ranges. The values of coefficients of variation of the length of the longest leaf (10.65$-74.67 \%)$ and width of bract $(28.3-72.97 \%)$ had significantly larger ranges than in the population from Kopanina. With regard to the E. palustris population from quarry in Opole (Mróz \& Rudecki 1995) only width of bract (26.4-51.7\%) and number of leaves $(12.7-13.7 \%)$ were smaller than in the population from "Kopanina". Other traits were more variable.

In summary, the currently investigated E. palustris population, growing on the site of anthropogenic origin, despite the negative human impact, is now in good condition. It has large size and consists of fully developed, equal in height ramets, with a large number of flowers. As it has been proved above, populations of this species on sites anthropogenically transformed may be very numerous and expansive. Their population numbers may be much higher than in the populations from natural sites. But it is not a rule and probably it mainly depends on habitat conditions.

\section{CONCLUSIONS}

Currently studied E. palustris population is in a good condition. Dominant share of the ramets in generative phase as well as prevalent part of orchids of medium size, confirm this observation.

During the study the population numbers fluctuated. Probably it was due to biology of the species, but only to a small extent to the impact of weather conditions.

Strong anthropopressure, caused by penetration of the area by the local residents, may adversely affect the existence of orchid population within the Kopanina in the future.

Population orchid requires protective activities involving the prevention of overgrowth of its habitat by other more expansive plant species.

\section{REFERENCES}

Antkowiak W., Pankros J. (2000): Charakterystyka ekologiczna populacji kruszczyka błotnego (Epipactis palustris (L.) Crantz) z Wielkopolskiego Parku Narodowego. Roczniki Akademii Rolniczej w Poznaniu 322, Ser. Botanika 3: 3-11.
Bernacki L. (1999): Storczyki zachodniej części polskich Beskidów. Colgraf-Press, Poznań.

Brzosko E. (1998): Dynamika wyspowych populacji Cypripedium calceolus L. In: Materiały Konferencyjne 51 Zjazdu PTB, Gdańsk. Ed. J. Miądlikowska. Bogucki Wydawnictwo Naukowe, Poznań: 61.

Brzosko E., TaŁąaj I., WróblewsKa A. (2006): Genetic structure of rare Epipactis atrorubens populations from two national parks in Northeast Poland. Polish Botanical Studies 22: 71-80.

Brzosko E., Wróblewska A., Tałazaj I. (2004): Genetic variation and genotypic diversity in Epipactis helleborine populations from NE Poland. Plant Systematics and Evolution 248: 57-69.

Ehlers B. K., Pedersen H.A.E. (2000): Genetic variation in three species of Epipactis (Orchidaceae). Biological Journal of Linnean Society 69(3): 411-430.

Flesch A. (2013): W Poznaniu, na Kopaninie, była wielka wycieczka! Bociek 3(115): 24-27.

GAŁKA M., KASPER P. (2011): Palaeobotanical peat analysis on contemporary Epipactis palustris (L.) Crontz. (Marsh Helleborine) sites in north-eastern part of Poland. Studia Limnologica et Telmatologica 5(2): 67-75.

Golis A., Bednorz L. (2001): Charakterystyka populacji kruszczyka błotnego Epipactis palustris (Will.) Cr. w rezerwacie przyrody „Mielno” koło Konina. Roczniki Akademii Rolniczej w Poznaniu 334, Ser. Botanika 4: 71-81.

Jacquemyn H., Brys R., Hutchings M.J. (2014): Biological flora of the British Isles: Epipactis palustris. Journal of Ecology 102: 1341-1355.

Jacquemyn H., Lenaerts M., Tyteca D., Lievens B. (2013): Microbial diversity in the floral nectar of seven Epipactis (Orchidaceae) species. Microbiology Open 2(4): 644-658.

JakubSKa-Busse A., Kadej M. (2008): Pollination ecology of Marsh Helleborine Epipactis palustris (L.) Crantz on the Polish side of the Orlickie Mts. (the Central Sudety Mts.). Scripta Facultatis Rerum Naturalium Universitatis Ostraviensis 186: 247-252.

JakubsKa-Busse A., Kadej M. (2011): The pollination of Epipactis Zinn., 1757 (Orchidaceae) species in Central Europe - the significance of chemical attractants, floral morphology and concomitant insects. Acta Societatis Botanicorum Poloniae 80(1): 49-57.

Kala R. (2009): Statystyka dla przyrodników. Wydawnictwo Uniwersytetu Przyrodniczego w Poznaniu, Poznań.

Kluza M., MaciejewsKa I. (1998): Nowe stanowiska Listera ovata (L.) R. Br. i Dactylorhiza incarnata (L.) Soó w Poznaniu. Roczniki Naukowe Polskiego Towarzystwa Ochrony Przyrody „Salamandra” 2: 135-137.

KluZa M., Maciejewska I. (1999): Struktura populacji listery jajowatej (Listera ovata) oraz kukułki krwi- 
stej (Dactylorhiza incarnata) w obrębie użytków ekologicznych w południowo-zachodniej części Poznania. Roczniki Akademii Rolniczej w Poznaniu 315, Ser. Botanika 2: 67-76.

Kluza-Wieloch M., MaciejewsKa-RutKowska I. (2009): Population of Dactylorhiza incarnata (L.) Sóo (Orchidaceae) in south-western part of Poznań ("Kopanina I") - results of monitoring in the years 1997-2009. Roczniki Akademii Rolniczej w Poznaniu 388, Ser. Botanika-Steciana 13: 125-132.

Kolon K., KrawczyK J., KrawczyK A. (1995): Charakterystyka ekologiczna populacji Epipactis palustris (L.) Cr. znad jeziora Pomorze w Puszczy Augustowskiej. Acta Universitatis Wratislaviensis, Prace Botaniczne 63: 93-97.

Kowalkowska A.K., Kostelecka J., Bohdanowicz J., Kapusta M., RojeK J. (2015): Studies on floral nectary, tepals' structure, and gynostemium morphology of Epipactis palustris (L.) Crantz (Orchidaceae). Protoplasma 252: 321-333.

Kujawa-Pawlaczyk J., Pawlaczyk P. (2001): Rzadkie i zagrożone rośliny naczyniowe lasów Ziemi Łużyckiej i Łużyc. Regionalna Dyrekcja Lasów Państwowych w Zielonej Górze, Wydawnictwo Lubuskiego Klubu Przyrodników, Świebodzin.

Maciejewska-Rutkowska I., Rutkowski P., Kluza-Wieloch M., Andrzejewska M. (2008): Population of Epipactis palustris (L.) Crantz (Orchidaceae) and its participation in local plant communities within the ecological useland "Kopanina I" in Poznan city. Roczniki Akademii Rolniczej w Poznaniu 387, Ser. Botanika-Steciana 12: 45-51.

Matuszkiewicz W. (2006): Przewodnik do oznaczania zbiorowisk roślinnych Polski. Wyd. Nauk. PWN, Warszawa.

Mirek Z., Piękoś-Mirkowa H. (eds) (2008): Czerwona księga Karpat Polskich. Rośliny naczyniowe. Instytut Botaniki im. W. Szafera i Instytut Ochrony Przyrody, PAN, Kraków.

Mirek Z., Pięroś-Mirkowa H., Zając A., Zając M. (2002): Flowering plants and pteridophytes of Poland. A checklist. Krytyczna lista roślin naczyniowych Polski. W. Szafer Institute of Botany, Polish Academy of Sciences, Kraków.

Mirek Z., Zarzycki K., Wojewoda W., Szeląg Z. (eds) (2006): Red list of plants and fungi in Poland. Czerwona lista roślin i grzybów Polski. Instytut Botaniki im. W. Szafera, PAN, Kraków.

Mróz L., RudeCKi A.L. (1995): Występowanie i warunki ekologiczne Epipactis palustris (L.) Crantz w kamieniołomie przy cementowni „Odra” w Opolu. Acta Universitatis Wratislaviensis, Prace Botaniczne 63: 101-111.

Pį̨Koś-Mirkowa H., Mirek Z. (2003): Atlas roślin chronionych. Multico Oficyna Wydawnicza, Warszawa.

RozPoRZĄDZENIE Ministra Środowiska z dnia 9 października 2014 r. w sprawie ochrony gatunkowej roślin. (2014). Dz. U. RP, poz. 1409.

Szlachetko D., Skaku M. (1996): Storczyki Polski. Wyd. Sorus, Poznań.

Tazataj I., Brzosko E. (2008): Selfing potential in Epipactis palustris, E. helleborine and E. atrorubens (Orchidaceae). Plant Systematic and Evolution 276: 21-29.

Wolanin M., OkLejewicz K. (2011): Storczyki pogórza Przemyskiego dawniej i dziś. In: E. Brzosko, A. Wróblewska, J. Jermakowicz (eds). Storczykowate w Polsce: biologia i ochrona. Alter Studio, Białystok: 66-76.

www.weatheronline.pl/weather/maps/city?LANG = $\mathrm{pl} \& \mathrm{UP}=0 \& \mathrm{WMO}=12330 \& \mathrm{CONT}=\mathrm{plpl} \& \mathrm{NOR}$ $\mathrm{EGION}=0 \& \mathrm{CEL}=\mathrm{C} \& \mathrm{LEVEL}=150 \& \mathrm{ART}=\mathrm{MAX}-$ $\& \mathrm{R}=150$.

WyrzyKIEWICZ-RASZEWSKA M. (2001): Struktura populacji Epipactis palustris (L.) Crantz - nowego apofita we florze aglomeracji Poznania. Roczniki Akademii Rolniczej w Poznaniu 334, Ser. Botanika 4: 197-213.

Wyrzykiewicz-Raszewska M., Brzeg A., Kuświk $\mathrm{H}$. (2001): Interesujące stanowisko kruszczyka błotnego Epipactis palustris (L.) Crantz w Koziegłowach koło Poznania. Roczniki Akademii Rolniczej w Poznaniu 334, Ser. Botanika 4: 215-220.

ZARZYCKI K., MireK Z. (2006): Red list of plants and fungi in Poland. Czerwona lista roślin i grzybów Polski. Instytut Botaniki im. W. Szafera, PAN, Kraków.

ZARZYCKI K., SZelĄG Z. (2006): Red list of the vascular plants in Poland. In: Z. Mirek, K. Zarzycki, W. Wojewoda, Z. Szeląg (eds). Red list of plants and fungi in Poland. Instytut Botaniki im. W. Szafera, PAN, Kraków: 9-20.

For citation: KluZa-Wieloch M., MaciejeWsKa-RutKOWSKA I. (2015): Population of Epipactis palustris (L.) Crantz (Orchidaceae) in south-western part of Poznań. Steciana 19(4): 231-238. doi:10.12657/ steciana.019.023 